\title{
Issina G.I. \\ On the problem of verbal representation of aesthetic values in various cultures
}

Karaganda State University named after Ye.A. Buketov

(Kazakhstan, Karaganda)

doi: $10.18411 / s p c-26-03-2019-07$

idsp: sciencepublic-26-03-2019-07

Aesthetic values are the values of the figurative perception of the world in the process of any human activity based on the laws of beauty and perfection. There are objective content of aesthetic value and its subjective side, depending on the prevailing ideals of beauty, tastes, and artistic styles. Aesthetic values can appear in the form of natural objects (for example, a landscape), man himself, as well as spiritual and material objects created by man. Famous expression of F.M. Dostoevsky "Beauty will save the world" should be understood not in isolation, but in the general context of the development of mankind ideals.

Plato's principle in the field of aesthetics consists in uniting the internal and external, the object and the subject, knowledge and feelings, the whole and the particular, the material and the ideal. With this approach, beauty appears as a kind of connection, the mutual representation of the material and the ideal. For Plato, heaven, cosmos, the universe, taken as a whole, act as the highest reflection of the idea of beauty [1].

The idea of beauty has never been considered separately; it has always been associated with ideas of love, justice, and goodness. Such an approach ensures the integrity of the value field. Such an approach ensures the integrity of the value field. Aesthetic values are presented both at the level of life of individuals and societies as a whole, and at the level of cultural phenomena. The aesthetic unity of the world and man is fully embodied in the value of beauty, because 'beauty' implies an individual perception that occurs spontaneously on the living level and quite consciously on the cultural level.

In linguistics, the analysis of value preferences opens up broad opportunities for the study of national linguistic consciousness, the construction of a language personality model. Language as a phenomenon of culture captures and reflects in some indirect way both the system of values, moods, assessments that currently exist in a given society, and values that are eternal for a given culture [2]. Moreover, the language, continuously interacting with culture and thinking, forms a native speaker as a person belonging to a given socio-cultural community, imposing and developing a value system, morality, behavior, attitude to people.

The vocabulary with which the aesthetic evaluation was carried out did not arise on its own; it is a reflection of the human perception of the environment, expressing his spiritual needs and aspirations. Phraseology most fully represents the aesthetic picture of the language in its dynamics and life-giving integrity. Phraseological units associated with the aesthetic concept of "beauty", as a rule, contain certain semantic characteristics, such as the names of the evaluation of the external characteristics of the object; a set of external and internal characteristics of a person causing this or that attitude to him; giving or assigning to someone or something certain characteristics.

In the phraseological picture of the world, special attention is paid to the beautiful appearance of a person, expressed by such phraseological units as: as pretty as picture, as handsome as a young Greek god, as handsome as paint, as shining as star. In English, the ease and grace are assessed in the gait and movements of women. The beauty of women's movements is associated with air and water elements in the minds of English speakers. For ex.: graceful as a bird on the wing, as the swallow's flight, as a butterfly, as the greenly waving boughs in summer wind, dance like a wave of the sea. The main attributes in describing a person's appearance are those visually perceptible characteristics that can be compared with the standard. 
In the French linguistic culture there is an opinion about female beauty as a phenomenon given to a woman on a subconscious level: "Les femmes réalisent la beauté sans la comprendre", that means "Women realize beauty without understanding it". Women only "realize" it (réalisent), that is, they are the bearer of beauty. The French linguoculture emphasizes the enormous power of the effect of female beauty on men: "C'est une chose plus enivrante que le vin d'être une belle jeune femme" ("To be a young beautiful woman is to intoxicate more than wine). This comparison is not surprising in French society, since the concept of wine is very significant for the French, like the woman, it is an integral part of the French mentality, a purely French attitude to life, which they call "la joie de vivre".

In Russian linguistic culture, the standard of feminine beauty is presented in the form of a portly woman with a healthy blush, which is referred to as "blood with milk", stepping smoothly, stately, unhurriedly, "like a white swan" floating with a regal appearance. In the Russian language consciousness, blue eyes are considered the most beautiful ones. Blue eye color is associated with beauty of the soul, moral purity: "eyes like cornflowers", "like pansies" [3].

The nuclear lexeme representing the concept 'beauty' in the Kazakh language is the lexеme «сұлульқ»,, «әдемілік» (beautiful, nice). Representations of the Kazakh people about beauty were more traditional. Big black eyes ('жұлдыз көз' - 'eyes like stars') were of high value among external characteristics. For Kazakhs, the canon of beauty is considered to be a light skin. Comp.: ақ білек (beautiful white hand), ақ дидар (white face), ақ құба (light skinned), ақ̧ша бет (white-faced).

In the Kazakh national language consciousness, the word 'beauty' is most often associated with animals. Comp.: кер маралдай керілдi, құралай көз (eyes like a roe deer has), бота көз (eyes like a little camel has).

In traditional Chinese philosophy, beauty is often manifested in the unity of man and nature, since man is a product of natural and higher forces. Man and the power of nature - this is the unity and opposite of 'yin' and 'yang', who strives for each other, but at the same time, repels each other. Beauty is born and manifested in the unity of opposites, in Chinese aesthetics it can be elegant, refined 优美 you mei, and can be majestic and monumental 壮美 zhuang mei. In Chinese, "beautiful”, "beauty" is denoted by the hieroglyph mei 美, which has the exact origin. In the ancient etymological dictionary, its interpretation related to the taste of goat's meat is clearly traced. In ancient China, it caused a certain aesthetic pleasure, close to the concept of beauty. The key hieroglyph of 美 mey can convey the meaning of "happiness", "well-being" [4]. In Chinese, human beauty is often compared with images of nature; there are a large number of enduring metaphors and comparisons that liken beautiful appearance (especially female) to the beauty of nature.

Thus, the studies of the verbal representation of "beauty" indicate that this aesthetic concept is one of the main human emotional-sensual mental formations. Beauty in everyday understanding is what causes a feeling of admiration, the desire to admire something. It is associated with an instinctive understanding of beauty, on the one hand, and the canons of beauty that have developed in society, on the other. Beauty as an aesthetic value is one of the most important cultural terms that exist in each language and are relevant to each person. On the one hand, the concept of "beauty" has a culturological incarnation, and on the other, linguistic designation. The national-cultural specificity of the perception of the world by a certain people is determined by many features that postpone the imprint on the reflection of the world in human consciousness and in his language. But with all the differences in the attitudes of different nations to "beauty", all are united by a certain intercultural and interethnic idea of beauty.

$$
* * *
$$

1. Leontev D.A. Tsennostnye orientats11 // Chelovek. Filosofsko entsiklopedicheski1 slovar. M., 2000. S.409.

2. Golovanova A.V. Tsennost1 1 otsenk1 v razykovom otrajenı1: D1s. ...kand.filol.naýk. Perm, 2002. 200 s. 
3. Rýsskoe kýltýrnoe prostranstvo: lingvokýltýrologıcheskı1 slovar. Vyp. 1. - M., 2004.

4. Pak A.O. Sopostavitelnoe issledovanie kontsepta «krasota» v kitaiskom 1 rýsskom iazykah: Avtoref...dis. kand. filol. naýk. - Dýshanbe: 2009. -25s. 